\title{
150STE BESTUURSVERGADERING,
}

GEHOUDEN 14 JUNI 1873.

Tegenwoordig de heeren Bleeker (Voorzitter), Wịnnmalen (Secretaris), van der Gon Netscher, Blommendal, 's Jacob, Kern, Meinsma, Niemann en Schlegel. Afwezig de heeren Robidé van der Aa, Sloet van de Beele en Millard; de beide eerstgenoemden met kennisgeving.

De notulen van het verhandelde in de vorige vergadering worden gelezen en goedgekeurd.

De Voorzitter doet mededeeling van de ontvangst van

I. de volgende ingezonden boekwerken:

Van het Ministerie van Koloniën :

Résumé's van het onderzoek naar de regten welke in de gouvernements-landen op Sumatra op de onbebouwde gronden worden uitgeoefend.

Regeerings-almanak en Naamregister voor 1873.

Van het Kon. Instituut van Ingenieurs:

Tijdschrift. 1872-1873. 4e afl.

Van de Academie van wetenschappen, te Weenen:

Sitzungsberichte der math. naturwissenschaftliche classe. 1873, no $12-15$.

Van de Academie van wetenschappen, te Berlijn:

Monatsbericht, Januari 1873.

Van de Royal Asiatic society of Great-Britain and Ireland:

Journal. vol VI, part III.

Van de Kon. Universiteit van Noorwegen, te Christiania:

G. Ossian Sars, On some ramarkable forms of animal life. 3e Volgr. VIII. 
Dr. Schübeler, Die Pflanzenwelt Norwegens. Anden Beretning om Ladegaardsoens Hovedgaard.

J. Lieblein, Recherches sur la chronologie Égyptienne.

M. G. Hetting, Die Fisch-cultur Norwegens.

Tromso Stift, Beretning om den almindelige Udstilling. The Thelemark race.

M. G. Hetting, Fortegnelse over de af Fiskeri-Inspektor for de norske Ferskvandsfiskerier.

Leasing of the waters, not containing fish, belonging to the Norwegian State.

Van de Société de géographie te Parịjs:

Bulletin, Avril 1873.

Van den heer Weitzel een ex. van zijn geschrift:

De krijgsgebeurtenissen op Celebes in 1859-1860.

Van den heer Clements R Markham, te Londen:

Ocean Highways. $n^{0} 3$, vol. I.

Van den heer Guido Cora, te Napels:

Cosmos. no 2 .

Van den heer A. de Gubernatis, te Florence:

La Rivista Europea. afl. Mei en Juni 1873.

Naar aanleiding van de inzending van het Juni-nommer van het door den heer Markham te Ionden uitgegeven tijdschrift "Ocean Highways" wordt de opmerking gemaakt, dat het Instituut daarvan ten vorigen jare ook eene aflevering, namelijk het nommer van Juli 1872, ontvangen heeft. Het Bestuur zou gaarne wenschen dat de ontbrekende nomıners in de Bibliotheek voorhanden waren, even alsdat de verder verschịnnende nommers geregeld werden toegezonden; het besluit wordt dus genomen den heer Markham met dien wensch bekend te maken, waaraan hịj ongetwijfeld wel zal willen voldoen, daar de Bijdragen geregeld aan zijn, adres worden afgezonden.

II de volgende stukken:

10. een proces-verbaal, opgemaakt en geteekend door de heeren A. D. van der Gon Netscher en P. J. Bachiene, de eerste als optredend, de tweede als aftredend peuningmeester, waarbij de eerste verklaart te hebben overgenomen en de tweede te hebben overgegeven de in het proces-verbaal genoemde waarden en stukken tot het finantieel beheer betrekkelịk.

Voor kennisgeving aangenomen. 
20. eene missive van den heer Mr. W. B. Bergsma, waarbij hịj verklaart de betrekking van Commissaris van het Instituut te aanvaarden.

Voor kennisgeving aangenomen.

30. eene missive van den heer H. G. J. G. Vriesman te Pamalang, waarin hij, in antwoord op het schrijven van het Bestuur van 12 Februari jl. mededeelt dat hị niet gerechtigd is de door wijlen den heer Hageman aan het Instituut vermaakte handschriften te verzenden, omdat de gemachtigde der executrice vermeent dat de boedel niet solvent is en daarom de nagelaten goederen moeten worden verkocht. Evenwel is genoemde gemachtigde genegen al de manuscripten aan het Instituut af te staan, indien het daarvoor een matigen prijs besteden wil. De heer Vriesman wenscht de beslissing van het Bestuur hieromtrent te vernemen.

De Vergadering is van oordeel dat het Instituut uit kracht van de uiterste wilsbeschikking een recht heeft op de gelegateerde handschriften, terwijl enkel wordt gezegd dat de boedel van wijlen den heer Hageman niet solvent is, zonder dat dit door eenige opgaven wordt gestaafd. Op voorstel van den Voorzitter besluit de Vergadering aan Commissarissen te Batavia op te dragen omtrent den stand van den boedel inlichtingen in te winnen, om daarna aan het Bestuur gelegenheid te geven met eenige meerdere kennis te beoordeelen of het de handschriften tegen betaling moet overnemen. Het zal later een punt van overweging uitmaken welke som, met het oog op de overgelegde lijst, het Bestuur daarvoor zou kunnen aanbieden.

40. eene missive van den heer A. May, Super-intendant of the rooms at Iıloyd's te Londen, waarbị hịj verklaart in de Bijdragen gelezen te hebben dat het Instituut een werk ter perse heeft gelegd van den heer von Rosenberg, zijnde het verhaal zijner reis naar Nieuw-Guinea. De heer May zou wenschen te vernemen of dit werk spoedig zal worden uitgegeven en geeft verder den wensch te kennen daarvan een ex. te ontvangen daar hịj zich voorstelt voor het Engelsch publiek een overzicht van dit werk samen te stellen.

De Vergadering toont zich bereid aan het verzoek van den heer May te voldoen en bij verschijning van het werk een ex. ter zijuer beschikking te stellen. Bij de mededeeling daarvan 
aan dèn heer May, zal hem de vraag worden gedaan of hịj zich voorstelt eene Engelsche vertaling van het geheele werk te leveren. Van de zijde van het Bestuur bestaat daartegen geene bedenking, omdat het aan het Instituut niet anders dan aangenaam kan zijn dat de werken, die het uitgeeft, door overzetting in eene vreemde taal, in een ruimer kring van lezers verspreid wordt. Mocht de heer May eene geheele vertaling bedoelen, dan is het Bestuur bereid, wanneer de heer May daartoe het verlangen openbaart, hem de afgedrukte vellen, naar mate die gereed komen, toe te zenden, zoodat hij reeds terstond met zijn arbeid een aanvang zou kunnen maken.

50. missives van de Ministers van Bimuenl. en van Buitenlandsche Zaken, de eerste berichtende dat hij, bij verschijning van het werk van dr. G. Schlegel, wellicht enkele exx. voor rekening van zijn departement zal nemen; de tweede meldende dat op de begrooting van zijn departement geene gelden beschikbaar zijn om de kosten te bestrijden van een zeker getal exx. van het bedoelde werk.

Aanneming voor kennisgeving.

Uitgave van het werk van dr. G. Schlegel, Uranographie Chinoise. De Secretaris zegt dat ten gevolge van de verhooging der oplage van 700 tot 750 exx. en van het kiezen eener andere papiersoort, de uitgaven voor dit werk eenigszins hooger, moeten gesteld worden. Het totaal wordt nu geraamd op $f 3382.40$.

Het Bestuur stemt in deze verhooging toe en keurt tevens het concept-contract goed met de firma Brill voor de uitgave van het werk aan te gaan.

Opstel van den heer Uilkens te Tjamis, bevattende vertellingen aangaande Iman Sapie. De heer Niemann, in wiens handen dit stuk is gesteld, zegt dat het niet geschikt is ter opneming in de Bijdragen, in de eerste plaats omdat de inhoud van het Soendaneesche stuk zeer onbeduidend is, maar in de tweede plaats - en dit is de voorname reden - omdat het geschreven is in versmaat, waarin reeds vele Soendaneesche stukken gepubliceerd zijn. Voor de taalstudie hebben dergelijke stukken minder waarde, daar de taal verwrongen wordt naar de versmaat. 
Reden waarom hij adviseert het stuk niet ter opneming in de Bijdragen te bestemmen.

Dienovereenkomstig wordt besloten.

Verslag van den heer Matthes van de in Europa aanwezige Makassaarsche en Boegineesche handschriften. De commissie, bestaande uit de heeren Kern en Meinsma, verklaart met genoegen het stuk gelezen te hebben, maar zij meent dat het voor verkorting vatbaar zou zijn, door samenvoeging der nommers en door de teksten, vooral wanneer het vertalingen van maleische handschriften, wier inhoud bekend is, zijn, niet zoo uitvoerig te refereeren. Verder zou de commissie in overweging geven het stuk niet in zijn geheel maar in twee of drie gedeelten in de Bijdragen op te nemen, bijv. eerst de Makassaarsche, en daarna de Boegineesche. Doet men dit niet, dan zou de vraag moeten opgeworpen worden of het als afzonderlijk stuk zal worden uitgegeven, maar daarvoor is het, naar het oordeel der commissie, niet genoeg van algemeen belang.

De Vergadering vereenigt zich met dit advies en draagt den Secretaris op den heer Matthes daarvan mededeeling te doen.

Opstel van den heer dr. A. Bruining, predikant te Etersheim, bevattende eene vertaling van Cankara ÂAarya's commentaar op de Aphorismen van den Vedanta. De Secretaris zegt dat hịj van het gedeelte van het opstel, dat aan het Instituut is ingezonden, met belangstelling kennis heeft genomen. De arbeid verdient ongetwijfeld meerdere bekendheid. De Secretaris heeft echter een paar opmerkingen. 10. Voor eene afzonderlijke uitgave is het minder geschikt en voor eene plaatsing in één nommer der Bijdragen is het te uitvoerig. Het opstel wordt begroot op 300 blz. Mocht door het Bestuur besloten worden het in de Bijdragen op te nemen, dan zou het overweging verdienen het bij gedeelten in eenige achtereenvolgende afleveringen te plaatsen. 20. Aan het opstel ontbreken inleiding en aanteekeningen: Het zou althans wenschelijk zijn dat eene inleiding aan het opstel werd toegevoegd.

Ten opzichte van dit laatste punt verklaart de heer Kern zich bereid eene inleiding te leveren. Het geven van aanteekeningen zou hị niet durvan aanraden, omdat de aanteekeningen licht even uitroerig zouden worden als het opstel zelf. 
De Vergadering besluit den heer Bruining mede te deelen dat het Bestuur tot openbaarmaking van zijn arbeid bereid is, mits hij er in toestemme dat het opstel bij gedeelten in de Bijdragen wordi opgenomen. Met welgevallen neemt het Bestuur voorts het aanbod aan van den heer Kern om aan het opstel eene inleiding toe te voegen.

De heer van der Gou Netscher vraagt het gevoelen van het Bestuur ontrent de opneming in de Bijdragen van opstellen over de kolonisatie. Hij zou het toch wenschelijk achten dat bijv. door het stellen van vragen wetenschappelijke opgaven werden uitgelokt van hetgeen tot heden voor kolonisatie is gedaan. Dergelijke geschiedkundige mededeelingen hebben actueel belang, omdat in den laatsten tijd herhaaldelijk op het doen van proefnemingen wordt aangedrongen. De Vergadering verklaart in te stemmen met den wensch om opstellen over dit onderwerp uit te lokken en besluit dus in de Bijdragen te vermelden, dat het Bestuur van het Instituut wenscht te ontvangen een historisch onderzoek naar den uitslag van de pogingen tot kolonisatie met Europeanen in Oost- en West-Indië of in andere tropische gewesten.

Op voorstel van den heer Kern wordt besloten tot buitenlandsch lid van het Instituut te benoemen den heer dr. Albrecht Weber, te Berlijn.

De vergadering wordt hierna gesloten. 